\title{
Preliminary geochemical study of Puyango deposit, Ecuador, applying statistics
}

\author{
J. L. MANRIQUE ${ }^{1,2 *}$, J. E. ORTIZ ${ }^{2}$ \\ ${ }^{1}$ Universidad Técnica Particular de Loja, Loja, San Cayetano \\ Alto, PO BOX 11-01-608, Ecuador (*correspondence: \\ johnmancar@gmail.com) \\ ${ }^{2}$ Universidad Politécnica de Madrid, ETSI Minas y Energía, \\ C/Ríos Rosas 21, P.O. Box 28003, Madrid, España; \\ joseeugenio.ortiz@upm.es
}

\section{Introduction}

A geochemical study of the $\mathrm{V}, \mathrm{U}$ and $\mathrm{Zn}$ cretacic deposit of Puyango, Ecuador, in bituminous limestones, has been carried out, making multielemental chemical analysis (ICPMS) and total organic carbon (TOC), as well as multivariate statistical analysis, including: correlation coefficients, cluster analysis and factor analysis of elements and rocks samples to determine geochemical associations.

\section{Discussion of Results}

Through factorial geochemical analysis, four geochemical associations can be inferred mainly: 1) disseminated organic matter in the limestones in which $\mathrm{V}$ and $\mathrm{Zn}$ are hosted, forming perhaps organometallic complexes [1, 2], 2) phosphatic minerals that contain high concentrations of $U$, HREE and $\mathrm{Ni}$ as trace elements [3], probably both associations formed during sedimentation in an anoxic environment, 3) carbonates (Ca) forming calcite in a marine environment, which corresponds to the geological descriptions of the Fm. Puyango and, 4) detritic minerals such as quartz, plagioclase, feldspar, micas, clays and oxyhydroxides of $\mathrm{Fe}-\mathrm{Mn}-\mathrm{Ti}$, product of the clastic contribution within the sedimentary basin.

$\mathrm{V}$ is mainly associated with the organic matter of marine origin disseminated in the bituminous limestones [1], inorganic $\mathrm{V}$ may have formed (vanadate minerals have been identified as sherwoodite and ronneburgite, previously). Finally, $U$ is associated with $P$ in the analyzed samples, which indicates that uraniferous phosphates must have formed during sedimentation (apatite and uranosphatite have been identified previously).

[1] Gao, Y.Y., et al., Vanadium: Global (bio) geochemistry, Chem. Geol. 417 (2014) 68-89. [2] Scott, C., et al., The hyper-enrichment of $\mathrm{V}$ and $\mathrm{Zn}$ in black shales of the Late Devonian-Early Mississippian Bakken Formation (USA). Chem Geol. 452 (2017) 24-33. [3] McArthur, M., and Walsh, N. Rare-earth geochemistry of phosphorites. Chem Geol. 47 (3-4) (1984) 191-220 